\title{
Guitar Hero? My hero!
}

\author{
Judith Way
}

2 Redleap Avenue, Mill Park 3082 Victoria, Australia. way.judith.j@edumail.vic.gov.au

\section{Introduction}

Guitar Hero is a video game where one or more players use a specially made game-style guitar to play along to popular and well-known songs. Players need to match the correct notes and timings of the sings. An onscreen guide shows players which notes to play, when. There are levels of difficulty in the game, as well as the choices to play with or against other players. Players can select from bass, rhythm or lead guitar and the program adjusts the difficulty of play accordingly.

I have been interested in gaming as a way of enhancing learning since I first played Guitar Hero with my nephew a few years ago. He was proficient at the game and was a great teacher, showing me what to do so that we could play well together. After a full day's playing, we were both still engaged and interacting constantly on and off the screen. For a teenage boy to spend the entire day engaged in an activity with his middle-aged aunt is a modern miracle in my book, and the fact that we both enjoyed the day and I learned from him was a real bonus.

In February 2009, the Victorian Department of Education and Early Childhood Development's Collaborative Research and Learning Program called for schools interested in trialling gaming for learning via a $\$ 4000$ grant: \$2000 for software and hardware, and \$2000 for CRT release time. After my Principal's endorsement, I applied for the program. The timeline was tight and there was no time to propose involvement in the trial to other teachers. So the decision was made for me to trial the use of the Nintendo DS and the My Word Coach program for a small literacy class of five students for a period of eight weeks. This trial was very successful and saw increases in attendance, punctuality, attitude and achievement. The success of the program and the concept of using video games for learning were introduced as a real and important way to address learning engagement in my school, Preston Girls' Secondary College.

After this successful trial with Year 8 and 9, I introduced the idea of using gaming at the Victorian Certificate of Applied Learning (VCAL) level (alternative Year 12) to teacher Les Kyle as a possible way of approaching the literacy and numeracy aspects of the course in a totally different manner. By using a program such as Guitar Hero: World Tour, we knew that students would be learning while enjoying themselves. As we know, that's when we best learn. So rather than trying to teach dry literacy and numeracy tasks with students often 18 years of age, we decided that the use of the video game and extended responses using social networking and other Web 2.0 tools would be ideal for this audience.

The advent of using the Guitar Hero: World Tour video game as a learning tool began as a collaborative piece of work between VCAL (alternative Year 11 and 12 program) teacher Les Kyle and myself. We conducted all of the planning and purchase of the items in Term 4, 2009 (October - December), and not only enjoyed collaborating together, we were excited at how the students might respond. On several occasions when we were setting up the game, current VCAL students would enquire about what was happening, offer to help us and generally express delight at the idea.

Les and I collaborated closely over the three month lead-up period in late 2009 to fine tune the tasks for the students. I began a wiki so that we could work individually and collaboratively on the project as time allowed: see Preston Girls' SC Guitar Hero wiki. The wiki will form the backbone of the project. Students will create blogs to journalise their tasks which will link back to the wiki. We want the activities to be challenging and enjoyable, but achievable and realistic. See the wiki for more information on tasks. 
However, at the beginning of 2010 I was seconded to develop a Personal Learning Network online learning program for the State Library of Victoria and the School Library Association of Victoria, which led to me taking leave without pay from Preston Girls' Secondary College for three terms. This affected the program and will be discussed later.

\section{The Program}

The students were to form a group and then develop an imaginary band. The idea was for them to create all aspects of a band, from their history, to their name, whether they used their real names or developed onstage personas.

Each band was required to start a blog and begin posting about the band and a proposed world tour. This included:

- selecting arenas to play in,

- naming the world tour,

- naming previous $\mathrm{CD}$ releases,

- designing CD covers,

- participating in media interviews,

- developing and promoting merchandise, such as programs and t-shirts,

- designing tickets,

- developing advertising such as billboards,

- creating avatars to use in online publicity (if students didn't want to use their own images online),

- deciding how much their concert tickets would sell for,

- estimating costs of holding the tour,

- deciding how they would tour the world and where they would stay,

- creating itineraries for travel from city to city and concert to concert,

- listing types of numbers of employees needed, and

- deciding how to pay for employees. The concerts had to be financially successful.

The tasks set all aligned with both the VCAL expectations and standards, including these from the VCAL Curriculum Planning Guide:

- Delivery and teaching strategies for VCAL learning programs should be based on adult learning and youth development principles including:

- curriculum content negotiated to build on the student's interests, abilities and strengths. Here students were able to take responsibilities for their specific interests. One student could do calculations and excel spreadsheets, one could write blog posts, and one could film media interviews. Or they could share tasks equally. It was up to students how to approach and allocate tasks.

- curriculum content that focuses on practical 'hands-on' opportunities for learning. Students were writing blog posts for a world-wide audience; their creations of merchandise were to be added to the blog, so all of this was very hands-on.

- curriculum content and delivery strategies that encourage personal development and growth and include opportunities to integrate learning across the learning program. Students were responsible for their own learning and the progress of their own group. Students could be as creative and put as much into their project as they wanted. Using mainly both numeracy and literacy skills for the project, other subject skills such as art and music were also used.

- recognition of student achievement and student contributions that is both formal and informal. Student achievement was recognised in a number of ways: within their group, by the whole class, by the teacher, by the world-wide blog audience, or by the other schools visited.

(C) 2010 IASL, SLAQ and therein by the authors. Diversity Challenge Resilience: School Libraries in Action Proceedings of the $12^{\text {th }}$ Biennial School Library Association of Queensland, the $39^{\text {th }}$ International Association of School Librarianship Annual Conference incorporating the $14^{\text {th }}$ International Forum on Research in School Librarianship, Brisbane QLD Australia, 27 September - 1 October 2010. 
- curriculum and delivery strategies that enable students to learn at their own pace. Students can work at their own pace as they have been able to select the aspects of the program for which they will take responsibility.

- curriculum and delivery strategies that enable students to learn in different ways according to different learning styles. Different learning styles have been catered for as there is handson work, writing and numeracy skills, and performing and creating tasks.

- delivery and assessment that assists the individual to achieve positive educational outcomes. Students can select their area of strength to contribute to; all group members are equal and have an equal and shared role.

- curriculum that values and engages the contribution of young people. By using videogames and Web 2.0 tools such as blogs, young adults are engaged both by the actual game and by communicating with a large audience.

- curriculum that builds competence and resilience in individuals including minimising risk factors and enhancing the promotion of protective behaviours of young people. Students were protected from any unsavoury blog comments as Les moderated all blog comments. The Guitar Hero program has levels of difficulty that can be set for each individual and changed as students progress.

- curriculum and delivery strategies that encourage civil and civic participation and promote active citizenship. Visiting other schools and even perhaps retirement villages and nursing homes is certainly a way for students to promote active citizenship.

- development of partnership approaches to program planning and delivery that link young people with the broader community. Students can ask primary school students to help them organise the Orientation Day competition.

The program was funded by using general VCAL funds allocated to the Literacy and Numeracy sections of the course. The school administration supported the purchase of a Playstation 3 console, the video game, guitars, drums as well as a large television. They supplied a permanent room for the class and secure storage for the game, console and television.

The school administration agreed that this program was a worthwhile one to enhance student learning at the VCAL level.

Students also have the opportunity to visit local primary schools to showcase what they have done and encourage students to play the Guitar Hero game with them. There is also the possibility of using the Guitar Hero game and the VCAL students to hold a competition on Orientation Day as a fun way of engaging new (and perhaps nervous) students.

As mentioned previously, my absence from school for the first three terms of the year and the introduction and implementation of the Guitar Hero program has affected its efficacy. I was the one who was pushing the project through and Les had confidence in me to solve any technical issues. Once I had begun my leave, the program's implementation faced several issues such as Les's lack of confidence in running the program alone, students needing mentoring from an extra teacher now not being given that time and a general lack of drive. I suppose nobody else in the college had the belief in the benefits of using Guitar Hero and it was easy to let things slide from week to week. Some aspects of the course have been completed, but not perhaps in the way Les and I had first envisaged. This is an important lesson: experimental programs such this need to have more than a couple of people dedicated to them. A working party of four or five committed teachers would be ideal to ensuring such projects kept their momentum.

\section{Conclusion}

As the $2010 \mathrm{~K}$-12 Horizon Report suggests, gaming for learning will become accepted mainstream education in two to three years. There is a lot of work to be done by schools before then and this is a step towards that. There may have been a few faltering steps taken, but we have learned a lot and hopefully the students have too.

(C) 2010 IASL, SLAQ and therein by the authors. Diversity Challenge Resilience: School Libraries in Action Proceedings of the $12^{\text {th }}$ Biennial School Library Association of Queensland, the $39^{\text {th }}$ International Association of School Librarianship Annual Conference incorporating the $14^{\text {th }}$ International Forum on Research in School Librarianship, Brisbane QLD Australia, 27 September - 1 October 2010. 
This stage of my career has been the most exciting ever. The use of gaming and Web 2.0 tools has opened the channels of collaboration between teacher-librarian and teacher, student and student, teacher and student so much more than was ever possible before. Hopefully it is also a very exciting time for students - those students at least who are being given creative opportunities to explore the new and ever-changing world that technology is bringing us.

Developing curriculum such as the Guitar Hero: World Tour project really raises the profile of the teacherlibrarian in the school and the region. It is rewarding to be seen not only as a teaching partner and supporter, but a curriculum innovator, and the nicest aspect of this project has been when Les Kyle called me her hero!

In the future, the program could be broader and include other subject areas if possible. Students studying desktop publishing and/or art could develop further merchandise materials, advertising posters, tour booklets and more.

School staff not involved in the program could be enticed to use the Guitar Hero game on a Friday afternoon after school to see just how engaging the game can be. Staff and the school community could be encouraged to add comments to students' blog posts. Students could perform a concert for the school community during open night or for local primary (elementary) schools.

At the time of writing, students were only in the early stages of the program and achievements will be discussed at the time of the conference.

\section{References}

Department of Education and Early Childhood Development. (2009). Collaborative learning and research program. Retrieved April 27, 2010, from http://www.education.vic.gov.au/researchinnovation/kbnextgen/evaluation/clrp.htm

Gaming for literacy learning. Retrieved April 27, 2010, from http://gaming4learning.wikispaces.com/

Guitar her. (2009). Retrieved April 27, 2010, from http://hub.guitarhero.com/

The New Media Consortium. (2010). 2010 Horizon report: The K12 edition. Retrieved April 28, 2010, from http://wp.nmc.org/horizon-k12-2010/

Preston girls guitar hero. (2009). Retrieved April27, 2010, from http://pgscguitarhero.pbworks.com/

Victorian Curriculum and Assessment Authority. (2008). Curriculum planning guide: Literacy and numeracy skills strand: Literacy skills units. Retrieved April 27, 2010, from

http://www.vcaa.vic.edu.au/vcaa/vcal/providers/resources/curricplanguidelns-literacyskills.pdf

Way, Judith. (2009). KnowledgeBank: Next Generation Project: Preston Girls' Secondary College gaming for literacy learning. Retrieved April 27, 2010, from http://gaming4learning.wikispaces.com/

(C) 2010 IASL, SLAQ and therein by the authors. Diversity Challenge Resilience: School Libraries in Action Proceedings of the $12^{\text {th }}$ Biennial School Library Association of Queensland, the $39^{\text {th }}$ International Association of School Librarianship Annual Conference incorporating the $14^{\text {th }}$ International Forum on Research in School Librarianship, Brisbane QLD Australia, 27 September - 1 October 2010. 